\title{
Seroprevalence of Hepatitis B and Hepatitis C: A Community Based Study Conducted in İzmir, Turkey
} Hepatit B ve Hepatit C Seroprevalansı: Izmir, Türkiye'de Yapılan bir Toplum Temelli Çalıșma

\author{
Şükran Köse', Aliye Mandıracıoğlu², Gülsün Çavdar', Yııdız Ulu', Melda Türken', Ayhan Gözaydın', \\ İlhan Gürbüz $z^{3}$, Șenol Sarıavcı' ${ }^{3}$, Neșe Nohutçu ${ }^{3}$ \\ ${ }^{1}$ Department of Infectious Diseases and Clinical Microbiology, Tepecik Educational and Research Hospital, İzmir, Turkey; \\ ${ }^{2}$ Department of Public Health, Ege University School of Medicine, İzmir, Turkey; ${ }^{3} \dot{I} z m i r$ Provincial Health Directorate
}

\begin{abstract}
AIM: To determine the seroprevalence rate and associated risk factors of hepatitis $B$ and $C$ virus infections in Izmir, Turkey.

METHODS: In this community-based cross-sectional study, 2737 healthy individuals over 14 years of age were included using a random sampling method. Serum samples were collected to study the presence of HBsAg, Anti-HBs, Anti-HBc total and Anti-HCV using the ELISA method. Data dealing with the socio-demographic characteristics and the risk factors for the infections was collected with a questionnaire.
\end{abstract}

RESULTS: HBsAg positivity was found in $2.8 \%$. Anti-HBs positivity and Anti-HBc total seropositivity were determined in $32.4 \%$ and $31.4 \%$, respectively. Anti-HCV positivity was found in $0.3 \%$. Illiteracy, previous hepatitis history, and family history of hepatitis were risk factors for HBsAg seropositivity in izmir. However, the risk factors did not affect the seropositivity rate of $\mathrm{HCV}$.

CONCLUSION: Izmir has a lower intermediate endemicity for HBV infection. Socioeconomic and environmental risk factors are important for HBV infection.

Key words: hepatitis $B$; hepatitis $C$; prevalence

\section{ÖZET}

AMAÇ: İmir, Türkiye'de hepatit B ve $C$ virüsü enfeksiyonları seroprevalansı ve birlikte görülen risk faktörlerini belirlemek.

YÖNTEM: Bu toplum temelli çalıșmada, randomize örnekleme yöntemiyle 2737 sağlıklı birey yer aldı. Serum örnekleri Elisa metoduyla HBsAg, Anti-HBs, Anti-HBc total ve Anti-HCV varlığını tespit için toplandı. Sosyo-demografik özellikler ve enfeksiyon için risk faktörü için veriler anket kullanılarak toplandı.

BULGULAR: HBsAg pozitivitesi \%2,8 bulundu. Anti-HBs ve Anti$H B c$ total seropozitivite oranları sırasıyla \%32,4 and \%31,4'tü. Anti-HCV pozitivitesi ise \%0,3'tü. Okur yazar olmamak, hepatit geçirmiș olmak ve aile hikayesinde hepatit olması, Izmir'de hepatit

Doc. Dr. Sükran Köse, Tepecik Eğitim ve Araștırma Hastanesi, Yenişehir, İzmir Tel.02324696969-1704Email.gakincioglu@hotmail.com

Geliş Tarihi: 28.07.2013 • Kabul Tarihi: 19.12.2013 seropozitifliği için risk faktörü olarak bulundu. Ancak, risk faktörleri HCV seropozitiflik oranını etkilemedi.

SONUÇ: Izmir'de HBV enfeksiyonu düșük orta derecede endemiktir. Sosyoekonomik ve çevresel risk faktörleri HBV enfeksiyonu için önemlidir.

Anahtar kelimeler: hepatit B; hepatit C; prevalans

\section{Introduction}

Hepatitis $B$ virus (HBV) and hepatitis $\mathrm{C}$ virus (HCV) infections are both considered as public health problems, and they are among the major causes of mortality and morbidity, particularly in developing countries. The fatality of these diseases is well known; 600.000 HBV-related deaths are estimated to occur annually and $73 \%$ of all liver cancer deaths worldwide are due to hepatitis viruses, with much higher proportions in low and middle income countries ${ }^{1}$.

HBV has the potential to deteriorate the health seriously. With its carrier rate of $20 \%$, it has become one of the most contagious agents threatening public health. Insufficient coverage of $\mathrm{HBV}$ vaccination, sharing blood-contaminated equipment by drug users, unsafe blood transfusions, and inadequate health precautions are major risk factors for hepatitis B virus infection in most developing countries ${ }^{2,3}$.

Currently, 400 million individuals around the world are infected with hepatitis B. Approximately $40 \%$ of them are associated with cirrhosis or hepatocellular carcinoma. In addition, one third of the global population has been exposed to hepatitis $B$ virus. Transmission routes of $\mathrm{HBV}$ can be classified in 4 major groups; parenteral, 
perinatal, horizontal and sexual. HBsAg infection levels have traditionally been described according to three categories of endemicity indicating the proportion of the population being seropositive for $\mathrm{HBsAg}$ as low $(<2 \%)$, lower intermediate $(2-4 \%)$, higher intermediate $(5-7 \%)$ and high $(\geq 8 \%)^{1,4,5}$.

Clinical manifestations of acute icteric hepatitis may develop in about $25 \%$ of cases with HCV infection. In around $70 \%$ of infected cases (range 50-85\%) chronic RNA positive disease develops. Cirrhosis develops over a 20 -year period. The possibility of developing cirrhosis is less than $5 \%$ and $20 \%$ in cases infected before and after 40 years of age, respectively ${ }^{6}$.

The role of HCV in chronic hepatitis has gradually increased in Turkey in recent years. Ökten reported that HBV infection is still important; however contribution of HCV has risen from $23 \%$ to $38.1 \%$ during the last decade. In other words, the contribution of $\mathrm{HBV}$ to cirrhosis decreased from $56.6 \%$ to $45.9 \%$ and the contribution of $\mathrm{HCV}$ rose from $25.2 \%$ to $45.9 \%^{7,8}$.

Prevalence of $\mathrm{HCV}$ infection around the world is predicted to be around $2.2-3 \%$. This means that approximately 130-170 million individuals are HCV-positive worldwide North America has the lowest HCV prevalence (less than $1 \%$ ), in contrary countries with high prevalence are located in Asia and Africa ${ }^{6,9}$.

$\mathrm{HBsAg}$ is the main clinical marker indicating acute or chronic infection. The prevalence and the endemicity of $\mathrm{HBV}$ infection is defined with the presence of $\mathrm{HBsAg}^{1}$. Antibodies against $\mathrm{HCV}$ are detected by sensitive and specific enzyme immunoassay tests to define the HCV infection ${ }^{10}$.

The large reservoir of patients worldwide who are chronically infected with HBV creates an enormous disease burden ${ }^{11}$. Turkey is in a non-endemic area for $\mathrm{HCV}$ infection; however has an intermediate seroprevalence level for $\mathrm{HBV}$ infection. In a previous study, HBsAg and Anti-HCV antibodies were positive in $4.0 \%$ and $0.95 \%$ of the included 5471 Turkish subjects, respectively ${ }^{12}$. Turkish surveillance system notifies $\mathrm{HBV}$ and HCV; however inadequate notifications may exist. Durusoy reported laboratory notification rates of $12 \%$ and $1-4 \%$ for $\mathrm{HBV}$ and $\mathrm{HCV}$, respectively ${ }^{13}$.

In this study we aimed to determine the seroprevalence rate and associated risk factors of hepatitis $\mathrm{B}$ and $\mathrm{C}$ virus infections in İzmir, Turkey.

\section{Methods}

This community-based cross-sectional study was conducted in İzmir located in the Aegean region of Turkey, between January and March 2010. The study was approved by the Ethics Committee of the İzmir Provincial Directorate of Health. All participants gave written consents before filling the questionnaires.

\section{Survey design and sample size}

The population of İmir was 3,739,353. The required responding sample size was calculated using the EpiInfo computer program (Centers for Disease Control and Prevention, Atlanta, Ga., USA). This led to a sample size of 2737 individuals with a confidence interval of $95 \%$, a sample error of $2 \%$ and a design effect of 2 , in case where the estimated seroprevalence of $\mathrm{HBs} \mathrm{Ag}$ was considered to be $2.5 \%$.

There were a total of 29 counties in the province. The size of the sample in each stratum (county) was calculated in proportion to the population. A total of 2737 healthy individuals over 14 years of age living in İzmir, selected using data from the İzmir Health Directorate by a random selection method, were determined as the target group. In cases where these individuals were inaccessible or rejected participation in the study, two substitutes for each individual were determined, again using a random selection method.

There has been an HBV vaccination program for neonates in Turkey since 1998. This group of vaccinated young people were excluded.

The questionnaire included questions regarding socio-demographic characteristics (age, gender, place of abode, educational level, family size and the socioeconomic level) and risk factors related with hepatitis virus contamination.

\section{Serology}

Blood samples of $8 \mathrm{cc}$ were obtained from participants using the Vacuette ${ }^{\otimes}$ Standard tube holder (BD vacutainer, Becton Dickinson, UK). All samples were centrifuged and the isolated serum was stored at $-20^{\circ} \mathrm{C}$. Presence of $\mathrm{HBsAg}$, Anti-HBs, Anti-HBc total and Anti-HCV were tested using the ELISA (Diasorin, Italy) method.

\section{Statistical analysis}

Data was evaluated using the SPSS 14.0 software program. Differences between personal characteristics 
were evaluated in terms of seropositivity. In data analysis, the chi-square test was used. Multivariate logistic regression analyses were performed to identify risk factors for hepatitis B virus sero-markers. In this model, the significant variables from the univariate analysis were included. $p<0.05$ was considered significant.

\section{Results}

Socio-demographic characteristics of the 2737 participant were summarized in Table 1 . Most individuals were living in urban areas. The mean age was $44.05 \pm 16.83$ (15-94). Most of the participants were married women graduated from elementary school. They were housewives in the low income group. The household number was 4 (1-13).

$\mathrm{HBsAg}$, Anti-HBs, Anti-HBc total and Anti-HCV were positive in $2.8 \%(\mathrm{n}=85), 32.4 \%(\mathrm{n}=886), 31.4 \%$ $(n=860)$ and $0.3 \%(n=7)$ of the participants, respectively. Anti-HBc total alone (presence of Anti-HBc total in the absence of HBsAg and Anti-HBs) was found $11.8 \%(n=323)$. The rates of seroprevalence of hepatitis markers in gender and age groups are summarized in Graphs 1-4.
Risk factors associated with the presence of hepatic markers are summarized in Table 2. HBsAg positivity was correlated with education, income, age and family history of hepatitis $(\mathrm{p}=0.001)$, history of previous hepatitis or jaundice $(\mathrm{p}<0.001)$, and sharing contaminated equipments $(\mathrm{p}=0.006)$ (Table 2$)$.

Anti-HBs positivity was correlated with education, income, age, area of abode, marital status, family history of hepatitis, and history of previous hepatitis or jaundice. Anti-HBc total positivity was higher among men, those who were illiterate, and in the lower income group. It was also associated with marriage, previous hepatitis and family history of hepatitis, history of surgery, history of ear piercing, and type of sexual relationship. Anti-HBc total alone was statistically associated with male gender, education, age, income, marriage, previous hepatitis and family history of hepatitis, history of surgery and dental therapy, and history of ear piercing (Table 3).

According to multivariate analysis, HBsAg seropositivity was higher in those illiterate, subjects with previous hepatitis history and with family history of hepatitis (Table 3). In addition, income, education, familial

Table 1. Socio-demographic characteristics of the study population

\begin{tabular}{|c|c|c|c|c|c|c|c|}
\hline & & $\mathrm{N}$ & $(\%)$ & & & $\mathrm{N}$ & $(\%)$ \\
\hline \multirow[t]{3}{*}{ Gender } & & & & Place of residence & & & \\
\hline & Male & 1020 & $(37.3)$ & & Rural & 851 & (31.1) \\
\hline & Female & 1715 & $(62.7)$ & & Urban & 1886 & $(69.1)$ \\
\hline \multirow[t]{7}{*}{ Education } & & & & Occupation & & & \\
\hline & Illiterate & 228 & $(8.4)$ & & Housewife & 1140 & (42.4) \\
\hline & Primary School & 1212 & $(44.7)$ & & Retired & 453 & (16.6) \\
\hline & Secondary School & 310 & (11.4) & & Student & 148 & $(5.4)$ \\
\hline & High School & 564 & $(20.8)$ & & Client & 134 & (4.9) \\
\hline & University & 399 & $(14.7)$ & & Worker & 237 & $(8.7)$ \\
\hline & & & & & Other & 574 & (21.4) \\
\hline \multirow[t]{4}{*}{ Marital status } & & & & Income / month & & & \\
\hline & Married & 2100 & $(76.7)$ & & $<1000$ & 1624 & (62.5) \\
\hline & Single & 485 & (17.9) & & $1000-2000$ & 683 & (26.3) \\
\hline & Divorced / Widowed & 119 & $(4.4)$ & & $>2000$ & 290 & (11.2) \\
\hline \multirow[t]{7}{*}{ Number of household } & & & & Age group & & & \\
\hline & $1-4$ & 2127 & (78.9) & & $15-19$ & 167 & (6.1) \\
\hline & $5-9$ & 545 & $(20.2)$ & & $20-24$ & 182 & (6.6) \\
\hline & $10+$ & 24 & $(0.9)$ & & $25-29$ & 238 & $(8.7)$ \\
\hline & & & & & $30-34$ & 276 & (10.1) \\
\hline & & & & & $35-39$ & 279 & (10.2) \\
\hline & & & & & $40+$ & 1559 & (57.0) \\
\hline
\end{tabular}




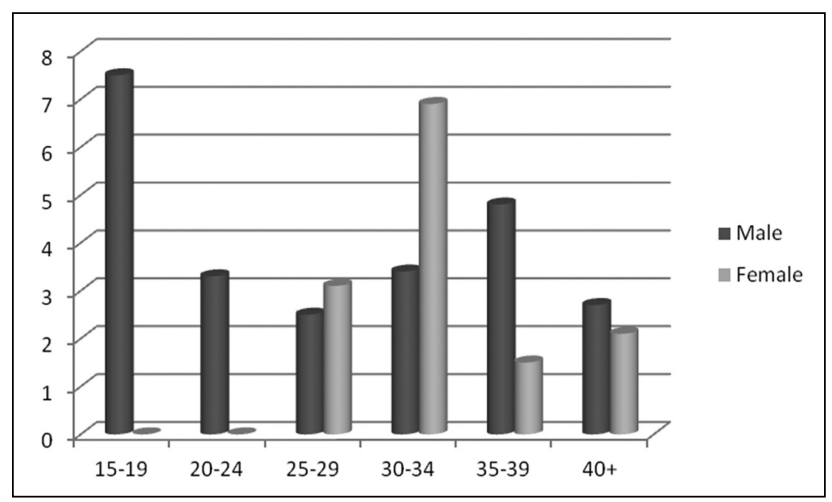

Graph 1. HBsAg seroprevalence analyzed using age groups and gender.

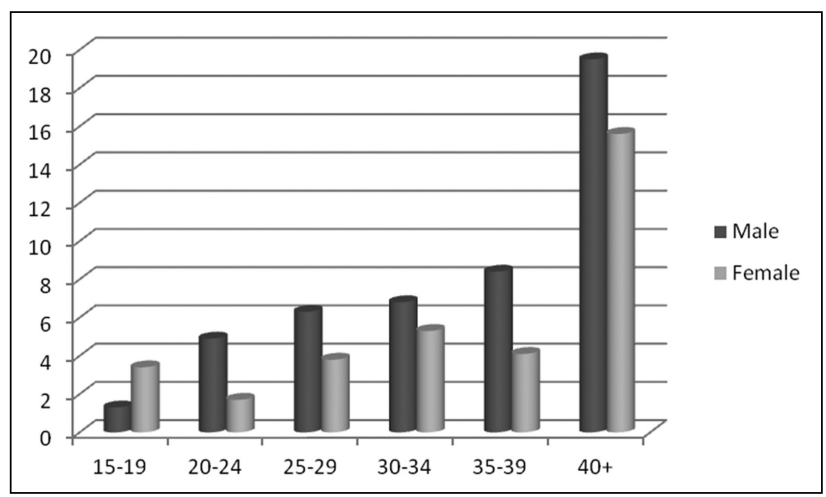

Graph 3. Anti-HBC seroprevalence analyzed using age groups and gender.

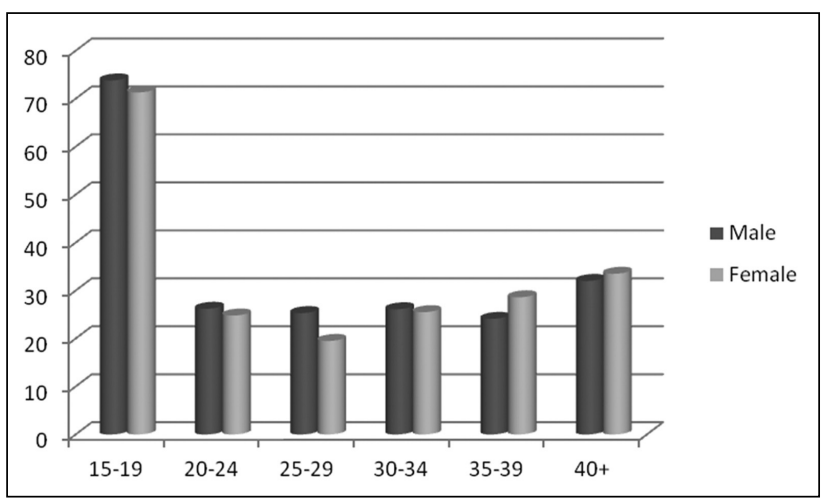

Graph 2. Anti-HBs seroprevalence analyzed using age groups and gender.

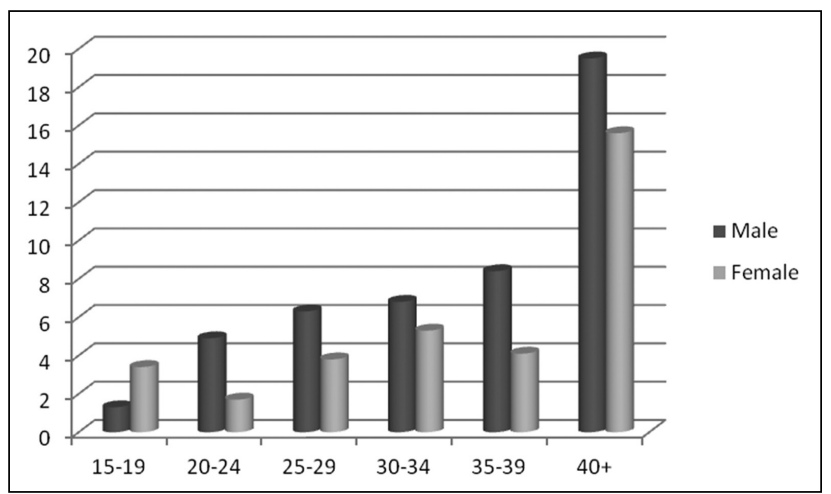

Graph 4. Anti-HBc total alone seroprevalence analyzed using age groups and gender.

Table 2. Distribution of risk factors for hepatic infection

\begin{tabular}{|c|c|c|c|c|c|c|}
\hline & & & \multicolumn{2}{|c|}{ Yes } & \multicolumn{2}{|c|}{ No } \\
\hline & & & $\mathrm{N}$ & $(\%)$ & $\mathrm{N}$ & $(\%)$ \\
\hline History of hepatitis / jaundice & & & 283 & $(10.4)$ & 2253 & $(83.1)$ \\
\hline Family history of jaundice & & & 497 & $(18.4)$ & 2070 & $(76.5)$ \\
\hline Staying in communal places & & & 1135 & $(50.2)$ & 1094 & $(48.4)$ \\
\hline History of surgery & & & 1299 & $(48.1)$ & 1371 & $(50.8)$ \\
\hline Dental therapy & & & 2072 & $(76.5)$ & 632 & (23.3) \\
\hline Blood/blood products & & & 134 & $(9.3)$ & 1272 & $(88.4)$ \\
\hline Being blood brothers & & & 223 & $(8.4)$ & 2333 & (87.5) \\
\hline Dialysis & & & 7 & $(1.6)$ & 442 & (98.4) \\
\hline Injecting drug/serum & & & 1830 & $(67.5)$ & 838 & $(30.9)$ \\
\hline Sharing tooth brush at home & & & 845 & $(31.2)$ & 1997 & $(68.6)$ \\
\hline Ear-piercing & & & 1634 & $(60.6)$ & 1064 & (39.4) \\
\hline Tattoo/piercing & & & 73 & $(2.7)$ & 2600 & $(97.2)$ \\
\hline Manicure/pedicure & & & 355 & $(12.3)$ & 2325 & $(87.7)$ \\
\hline Shared razor in barber & & & 341 & $(14.1)$ & 2077 & (85.9) \\
\hline Continuous intravenous drug & & & 34 & $(1.3)$ & 2670 & $(98.8)$ \\
\hline \multirow[t]{3}{*}{ Sexual activity } & & & \multicolumn{2}{|c|}{ Polygamous } & \multicolumn{2}{|c|}{ Inactive } \\
\hline & $\mathrm{N}$ & (\%) & $\mathrm{N}$ & $(\%)$ & $\mathrm{N}$ & (\%) \\
\hline & 2034 & (78.3) & 46 & (1.7) & 536 & $(20.0)$ \\
\hline
\end{tabular}


Table 3. Logistic regression to analyze the relation of risk factors with the markers. $P$ value $<0.05$ was considered significant.

\begin{tabular}{|c|c|c|c|c|}
\hline & HBsAg & Anti-HBs & Anti-HBc total & Anti-HBc total alone \\
\hline History of hepatitis & $<0.001$ & 0.231 & $<0.001$ & 0.001 \\
\hline Family history of hepatitis & $<0.001$ & $<0.001$ & 0.004 & 0.116 \\
\hline Manicure/pedicure & 0.532 & - & - & - \\
\hline Shared razor in barber & 0.339 & - & - & - \\
\hline Education & 0.020 & 0.005 & $<0.001$ & 0.033 \\
\hline Income & 0.113 & $<0.001$ & 0.001 & 0.001 \\
\hline Age group & 0.199 & $<0.001$ & 0.757 & $<0.001$ \\
\hline Marital status & - & 0.639 & 0.961 & 0.863 \\
\hline Place of residence & - & 0.175 & $<0.001$ & - \\
\hline History of surgery & - & - & 0.380 & 0.178 \\
\hline Previous dental therapy & - & - & 0.453 & 0.548 \\
\hline History of ear pearcing & - & - & 0.999 & 0.994 \\
\hline Sexual preference & - & - & 0.606 & - \\
\hline Gender & - & - & $<0.001$ & 0.320 \\
\hline Constant & 0.076 & 0.001 & $<0.001$ & $<0.001$ \\
\hline
\end{tabular}

history of hepatitis and age were all significantly associated with Anti-HBs positivity.

Male gender, illiteracy, lower income and urban residency, history of jaundice or hepatitis and family history of hepatitis were significant risk factors for Anti$\mathrm{HBc}$ total positivity. Risk factors for Anti-HBc total alone were illiteracy, lower income, older age and previous hepatitis history.

No relationship was found between HCV prevalence and socio-demographic characteristics and risk factors.

\section{Discussion}

The prevalence of HBsAg of $2.8 \%$ in İzmir was in lower intermediate range. Community-based studies dealing with the rate of $\mathrm{HBsAg}$ in İzmir are limited. Yazan-Sertöz et al. from İzmir determined that $\mathrm{HBsAg}$ positivity rate in 4537 blood donors was $2.3 \%{ }^{14}$. Afşar et al. reported that $1.38 \%$ of blood donors had HBsAg positivity ${ }^{15}$. Köse et al. reported that $2.2 \%$ of the barbers and hairdressing employees in İzmir were positive for $\mathrm{HBsAg}$ and $0.4 \%$ of them were positive for Anti-HCV ${ }^{16}$.

In a meta-analysis performed by Mistık et al., the $\mathrm{HBsAg}$ positivity rate was reported as $5.1 \%$ in approximately 5,420,125 units of blood collected by Red Cross blood centres in 13 years 5 . The communitybased studies conducted in Turkey reported various seroprevalence rates. In a study conducted by Kurt et al. the rate of $\mathrm{HBsAg}$ positivity was $5.5 \%$ among 3515 healthy individuals ${ }^{17}$. Yıldirım et al. found that $\mathrm{HBsAg}$ positivity was $5.5 \%$ in their study population selected using a random method in Tokat ${ }^{18}$. The seroprevalence of $\mathrm{HBsAg}$ was $7.0 \%$ in the south-eastern region of Turkey ${ }^{19}$. HBsAg positivity was $2.85 \%$ in Bolu ${ }^{20}$. The prevalence of $\mathrm{HBsAg}$, Anti-HBc total and Anti-HBs was found to be $6.0 \%, 29.3 \%$, and $30.3 \%$ respectively, in Malatya ${ }^{21}$.

History of previous hepatitis and family history of hepatitis were risk factors for having HBsAg positivity. Similar results were found in some studies conducted in developing countries ${ }^{22,23}$. According to a prevalence study in Turkey, living in urban areas, living in southeastern region of Turkey, being male, having close contact with an infected person, undergoing oral and dental interventions, having a history of transfusion, begin married, and history of travel abroad are the most common risk factors for Hepatitis B transmission ${ }^{12}$. Kurcer reported that $\mathrm{HBV}$ infection was independently associated with the age of 21 or higher, illiteracy, being 
farmer and worker, and having multiple sexual partners $^{21}$. Dursun et al. determined that the highest HBV infection prevalence was in the older age group and families with a history of jaundice ${ }^{24}$.

Anti-HBc total alone was found in $11.8 \%$ in our study. Ramezani et al. described that occult HBV infection is characterised by the presence of $\mathrm{HBV}$ infection without detectable HBsAg. These authors found that $2.07 \%$ of blood donors had Anti-HBc total alone ${ }^{25}$. Shi et al. suggested that occult HBV infection was associated with an increased risk of hepatocellular carcinoma ${ }^{26}$.

In our study Anti-HBs positivity was 31.4\%. Esfani reported that many years after recovery from acute hepatitis B, Anti-HBs had fallen to undetectable levels; and after many years of chronic HBV infection, the HBsAg titre had decreased below the detection cut off level ${ }^{27}$.

Anti-HBc total alone was found in $11.8 \%$ in our study. A few investigators have analysed Anti- $\mathrm{HBc}$ total alone in Turkey. The isolated Anti-HBc total seroprevalence rate was found to be $12.1 \%$ in Tokat $^{18}$ and $6.1 \%$ in Afyon ${ }^{28}$. There are several explanations for an isolated Anti-HBc total positivity, such as remote $\mathrm{HBV}$ infection and Anti-HBs that are no longer detectable or recent recovery from acute infection or undetectable levels of HBsAg in chronically infected patients or false positives ${ }^{29}$.

In our study, Anti-HCV prevalence was $0.3 \%$. Yildirim et al. determined that Anti-HCV prevalence was 2.1\% among healthy individuals in Tokat $^{18}$. Anti-HCV positivity was found to be $0.6 \%$ in the south-eastern region of Anatolia ${ }^{25}$. Akcam et al. reported that $1.0 \%$ of people were Anti-HCV positive in rural areas of the south-western region of Turkey ${ }^{30}$.

$\mathrm{HCV}$ infection varies according to geographic regions and time. Anti-HCV seroprevalence was reported as $0.54 \%$ in a total of $1,076,495$ units of blood ${ }^{1}$. In the study conducted in an İzmir hospital, the prevalence of Anti-HCV among blood donors was $0.42 \%{ }^{16}$. Similarly, Yazan-Sertöz et al. found a $0.3 \%$ rate of AntiHCV positivity among 4537 blood donors in İzmir ${ }^{14}$. Among blood donors, $0.35 \%$ had Anti-HCV positivity in İzmir ${ }^{15}$.

We could not demonstrate any factor that might play a role in HCV transmission. Similar results were found by Dursun et al. ${ }^{24}$. Akcam determined that Anti-HCV positivity was higher in hospitalized individuals ${ }^{30}$.
In our study, blood transfusion was not a risk factor for HBV and HCV. All blood donors in Turkey are mandatorily screened for HBV and HCV. Mandatory premarital hepatitis screening is also implemented in Turkey.

There were some limitations of the study. The questions relating to risk factors, especially regarding sexual preference and narcotic drug use might have been answered inaccurately.

Integrating $\mathrm{HBV}$ vaccination into the national immunisation programs and providing safe, effective treatment of HBV infection were efficient preventive measures and they were important for reducing the associated HBV-related morbidity and mortality.

The results indicate that the study area has a lower intermediate endemicity for HBV infection.

\section{Conflict of Interest Disclosure}

There is no conflict of interest.

\section{References}

1. Otta JJ, Stevensa GA, Groegerb J, et al. Global epidemiology of hepatitis B virus infection: New estimates of age-specific HBsAg seroprevalence and endemicity. Vaccine 2012;30:2212-9.

2. Lai CL, Ratziu V, Yuen MF, et al. Viral hepatitis B. Lancet 2003;362:2089-94.

3. Custer B, Sullivan SD, Hazlet TK, et al. Global epidemiology of hepatitis B virus. J Clin Gastroentrol 2004;38:158-68.

4. Alavian SM, Fallahian F, Lankarani KB. The Changing Epidemiology of Viral Hepatitis B in Iran. J Gastrointestin Liver Dis 2007;16:403-6.

5. Mistık R, Balık I. Epidemiological analysis of viral hepatitis in Turkey 6th ed. Ankara: Publication of Association Against Viral Hepatitis, 2003.

6. Lavanchy D. The global burden of hepatitis C. Liver Int 2009;29:74-81.

7. Ökten A. Etiology of chronic hepatitis, cirrhosis and hepatocellular carcinoma in Turkey. Current Gastroenterol 2003;7:187-91.

8. Tözün N. "Importance of HCV infection for Turkey" epidemiology and projects Hepatitis C Update Meeting 11-13 January 2008, İstanbul.

9. Alter MJ. Epidemiology of hepatitis $\mathrm{C}$ virus infection. World $\mathrm{J}$ Gastroenterol 2007;13:2436-41.

10. Pawlotsky JM. Use and interpretation of virological tests for hepatitis C. Hepatology 2002;36:65-73.

11. Lavanchy D. Hepatitis B virus epidemiology, disease burden, treatment, and current and emerging prevention and control measures. Journal of Viral Hepatitis 2004;11:97-107. 
12. Nurdan Tozun, Osman C. Ozdogan, et al. A nationwide prevalence study and risk factors for hepatitis $a, b, c$ and $d$ infections in Turkey. Hepatology 2010;52(S1):697A.

13. Durusoy R, Karababa AO. There has been an HBV vaccination program for neonates in Turkey since 1998, Completeness of hepatitis, brucellosis, syphilis, measles and HIV/AIDS surveillance in İzmir, Turkey. BMC Public Health 2010;10:71.

14. Yazan-Sertöz R, Pullukçu H, Altuğlu I, et al. Infection indicators among blood donors who frequently donate blood. Turk J Infect 2003;17:77-9.

15. Afsar I, Gungor S, Sener AG, et al. The prevalence of HBV, $\mathrm{HCV}$ and HIV infections among blood donors in Izmır, Turkey. Indian J Med Microbiol 2008;26:288-9.

16. Kose S, Mandiracioglu A, Oral AM, et al. Seroprevalence of hepatitis B and C viruses: awareness and safe practices of hairdressers in İzmir: a survey. Int J Occup Med Environ Health 2011;24:275-82.

17. Kurt H, Battal I, Memikoglu O, et al. Distribution of HAV, HBV, HCV seropositivity in terms of age and gender among healthy individuals in Ankara region. Viral Hepatit Dergisi 2003;8:88-96.

18. Yildirim B, Barut $S$, Bulut Y, et al. Seroprevalence of hepatitis B and $\mathrm{C}$ viruses in the province of Tokat in the Black Sea region of Turkey: A population-based study. Turk J Gastroenterol 2009;20:27-30.

19. Dursun M, Ertem M, Yllmaz s, et al. Prevalence of Hepatitis B infection in the South-eastern Region of Turkey: Comparison of Risk Factors for HBV Infection in Rural and Urban Areas. Jpn J Infect Dis 2005;5:15-9.

20. Karabay O, Serin E, Tamer A, et al. Hepatitis B carriage and Brucella seroprevalence in urban and rural areas of Bolu province of Turkey: A prospective epidemiologic study. Turk J Gastroenterol 2004;15:11-3.
21. Kurcer MA, Pehlivan E. Hepatitis B seroprevalence and risk factors in urban areas of Malatya Turk J Gastroenterol 2002;13:1-5.

22. Duong TH, Nguyen PH, Henley K, et al. Risk Factors for Hepatitis B Infection in Rural Vietnam. Asian Pacific J Cancer Prev 2009; 10:97-102.

23. Wang CS, Chang TT, Yao WJ, et al. Comparison of hepatitis $\mathrm{B}$ virus and hepatitis $\mathrm{C}$ virus prevalence and risk factors in a community-based study. Am J Trop Med Hyg 2002;66:389-93.

24. Dursun M, Ozekinci T, Ertem M, et al. Prevalence of Hepatitis C in adults in the south-eastern region of Anatolia: a communitybased study. Hepatol Res 2004;29:75-80.

25. Ramezani A, Banifazl M, Eslamifar A, et al. Serological pattern of anti-HBc alone infers occult hepatitis $B$ virus infection in high-risk individuals in Iran. J Infect Dev Ctries 2010;4:65861.

26. Shi Y, Wu YH, Wu W, et al. Association between occult hepatitis B infection and the risk of hepatocellular carcinoma: a meta-analysis. Liver Int 2012;32:231-40.

27. Esfahani AM. Assessment of $\mathrm{HBc}$ antibody in individuals with HBs antigen negative test. Turk J Gastroenterol 2012;23:31112.

28. Demirturk N, Demirdal T, Toprak D, et al. Hepatitis B and $\mathrm{C}$ virus in West-Central Turkey: Seroprevalence in healthy individuals admitted to a university hospital for routine health checks. Turk J Gastroenterol 2006;17:267-72.

29. Kim AI, Saab S. Interpretation of laboratory tests for diagnosing viral hepatitis. Hosp Physician 2004;40:15-9.

30. Akcam FZ, Uskun E, Avsar K, et al. Hepatitis B virus and hepatitis $\mathrm{C}$ virus seroprevalence in rural areas of the southwestern region of Turkey. Int J Infect Dis 2009;13:274-84. 